\title{
INFORMATION AND COMMUNICATIONS TECHNOLOGY CHALLENGES AS INSTRUCTIONAL MEDIA IN GAMBIA VOCATIONAL HIGH SCHOOLS
}

\author{
Manding Suso ${ }^{1, ~ *, ~ I s t a n t o ~ W a h y u ~ D j a t m i k o ², ~ M u h a m m a d ~ I m r o n ~ R o m a d h o n ~}{ }^{3}$, \\ Bubacarr Jobarteh ${ }^{4}$ \\ 1,2,3 Graduate School of Universitas Negeri Yogyakarta, Jl. Colombo No.1 Yogyakarta 55281, Indonesia \\ ${ }^{4}$ University of the Gambia, MDI Road, Kanifing, 3530, Serrekunda, Gambia \\ E-mail: susomanding@yahoo.com* \\ *Corresponding Author
}

\begin{abstract}
This study explores Information and Communications Technology (ICT) challenges for instructional media at five different Vocational High Schools in the Gambia. Three aspects of data were measured: computer knowledge, internet facilities, and instructional media. The method used in this study involved descriptive research. Data collection methods included closed-ended questioners. The population consists of 164 students from grade 10 class, 50 students from Saamasang, 25 students from Bottrop, 25 from John Pickering, 32 students from St. peter's, and 32 students from Mingdaw. SPSS 22 software was used to manage the gathered data. The data analysis technique was a descriptive and correlation analysis statistic. Correlation analysis serves to find out whether each school has the same challenges of ICT. Findings revealed that computer knowledge, internet facilities, and instructional media pose the highest challenges. This study concluded that the teachers have an excellent chance to improve applied ICT for enhancing quality learning in the Gambia.
\end{abstract}

Keywords: ICT, instructional media, vocational high schools

\section{INTRODUCTION}

The Gambia, a developing country, still has many issues to do with regards to its information and communications technology (ICT) sector, especially in vocational high schools. This study was conducted at five different vocational high schools. They are among the top listed vocational high schools in the west coast region of the country. ICT as a tool for facilitating the education and learning process, information technologies strategies bring about the effectiveness and inflexible development of professionally developing teachers. As a nation, the Gambia made a great strive to embrace the use and spread of ICT.

Today ICT provides a different approach to different researchers and educators. However, there are many kinds of ICT definitions. ICT, as an electronic technology used for accessing, processing, gathering, manipulating, presenting, and communicating information [1]. Today (ICT) serves as an essential learning tool in enhancing learning skills and ability, with the help of information technologies, audio-visual can be provided quickly.

The modern generation of the $21 \mathrm{st}$ century has brought remarkable change with the rapid growth of ICT rapid growth in societies[2]. ICT plays an essential role in education [3]-[7], and it is becoming an attractive topic in our daily life activities [8]. Hence, there is a demand for educational institutions to use ICT to impart teaching skills and knowledge in vocational schools. One needs to value the use of ICT in schools. Teachers can use technology to support the teaching and learning process and help the students to be successful. Instead of the teacher being the only source of help in a classroom, students can access websites, online tutorials, and more to assist themselves [9]. In general, technology is an application of science to solve problems. Nevertheless, it is vital to know that technology and science are different subjects that work hand-in-hand to accomplish specific tasks or solve problems.

On the other hand, The Gambia has improved in the process of communication and 
infrastructure. Telephone services are spread in rural and urban areas of the country to have access to communication. However, the development of communication systems still has serious obstacles. A high level of computer illiteracy in the educational sector is a severe problem in rural areas. Another problem is the inconsistent power supply (electricity) and the high costs of setting up such systems. Besides, some ICT challenges in The Gambia vocational high school include insufficient computers available for students and poorly equipped computer laboratory. Teachers and students also have limited awareness of ICT's importance, limited parental support, and motivation The most crucial problem is that the Wi-Fi available is not fast enough to be used by a certain number of students simultaneously.

Several students also did not know how to use computers, even though they become a learning gate for both teachers and students. Students followed the instruction on the computer monitor, receiving information for the correct answer [10]. Several people emphasize computer technology in schools because students need to be technologically literate in the 21 st century. The knowledge cannot be achieved in the classroom, in the west coast region vocational high schools. Computer illiteracy is rampant in the educational sector to used computers and the internet. Therefore, computer technology is an essential part of the environment to use as learning tools and solve real-world problems.

Four of the mobile companies operating in the country, as mobile GSM operators, deliver affordable networks all over the country. Many people used mobile phones for internet connection[11]. They will buy credit and convert it into data to browse. The connection system in the country is data and Wi-Fi connection. Many people still used mobile data connection than a Wi-Fi connection due to the few wireless connections across the country [12]. The country needs to restructure the internet system as we are in a modern world of technology, especially in educational sectors in the schools. The internet must work a stable connection for students and teachers to conduct research.

In the 21st Century, especially the technology evidence era, teachers are in charge of students who work and learn in the rapidly advancing technological world. Technology has now been brought to the doorstep into the classroom. Teachers use instructional media and technology to effectively facilitate planning, delivery, and reinforcement of student learning. The use of media and technology has now become an issue to deal with considering students of the 21st Century who are born in an era where technology becomes part of every aspect of human life, including education.

The most prevalent equipment of media technologies used in schools is textbooks and blackboards to modern technology such as a computer, internet video, and digital cameras [13]. According to Wallace \& Benson [14], instructional materials are used in classrooms or workshops for instruction or demonstration purposes by students and teachers. Learning can be accelerated with different instructional material because they help in learner attention during the instructional process.

The Gambian vocational schools as institutions are still using chalk and blackboard to teach students, instead of using instruction material to demonstrate it to students due to lack of facilities, personal computer, limited projector to show interesting video of learning material [15]. This study explores the challenges of ICT in these five Vocational schools as follows: Saamasang, Bottrop, John Pickering, St. Peter's and Mingdawin The Gambia, West Coast Region and determines the ways of improving ICT in Vocational High Schools in the region and country as a whole.

\section{METHOD}

The method used in this study involved descriptive research. Data collection methods included closed-ended questioners. The experts with significant experience, the Head of the 
electrical engineering education department at the graduate school of Universitas Negeri Yogyakarta, revised the questioner. The fivepoint Likert scale ranging from zero (0) strongly disagree, one (1) disagree, two (2) no option, three (3) agree, and four (4) strongly agree, used for the measurement. A hundred and sixty-four (164) students of grade ten completed the questioners. SPSS 22 software was used to manage the gathered data. The data analysis technique was a descriptive and correlation analysis statistic. Correlation analysis also serves to find out whether each school has the same challenges of ICT.

\section{RESULTS AND DISCUSSION}

\section{Computer Knowledge Quality}

The analysis focused on (a) computer knowledge, (b) internet facilities, and (c) instructional media based on a rigorous review, very strong, strong, strong enough, and weak. The results present in Figure 1. The total population of respondents in Saamasang was 50 students. Saamasang is a private vocational high school located in the Brikama west coast region of the country result revealed that 68.0 $\%$ of the respondents are weak in computer knowledge. Only $4 \%$ of respondents are secure in computer knowledge.

From the observation, in the school of Bottrop the total population of 25 respondents, $72 \%$ of the respondents are secure enough in computer knowledge, but only $8.2 \%$ of respondents are strong in computer knowledge, and $20 \%$ of respondents are weak in computer knowledge. while in John Pickering's total population of 25 respondents out of that, from the observation, $72 \%$ of the respondents are strong enough in computer knowledge. Moreover, from the total population of 32 respondents in St. peter's school, $37.5 \%$ of respondents are weak in computer knowledge. In Mingdaw school, out of 32 respondents, $48.6 \%$ of respondents are strong enough in computer knowledge, and only (28.1\%) of respondents have strong experience with the computer. This result shows that Saamasang students are weak in computer knowledge compared to the other four schools, and follow by St. Peter's school.

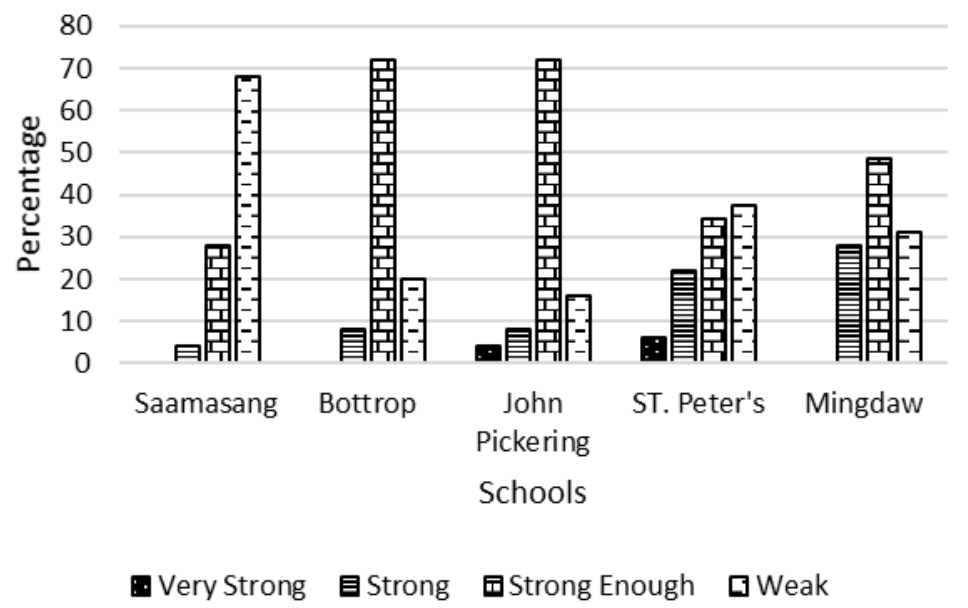

Figure 1. Data Categories of Computer Knowledge in Gambia Vocational Schools

\section{Internet Facilities Quality}

Internet facilities are a substantial factor in this study to determine the response and actions of the respondents related to the research questionnaire. It affects how people are aware of the internet as a supporting tool in learning[16]. The total population of 50 students from Saamasing, out of that, from the completed survey revealed that 58. $0 \%$ of respondents are secure enough to used internet facilities, but only $2.0 \%$ of the respondents are 
robust in internet facilities, and only $12.0 \%$ of the respondents are strong internet facilities. From the observation, in the school of Bottrop, the total population of Twenty-five respondents, $58.0 \%$ of respondents are strong enough in internet facilities, compare it to Saamasng school are the same while, $8.0 \%$ of the respondents are weak to use the internet in Bottrop. John Pickering school is located in the west coast region of the country. The school is a private school from this research the total population was 25 students out of that, $48.0 \%$ of the respondents are strong in internet facilities, and only $4 \%$ of respondents are weak to use the internet. While $78.1 \%$ of respondents from St. Peter's are reliable to use the internet, but $3.1 \%$ of the respondents are weak in internet facilities. The Internet literacies and the internet facilities in Mingdaw school, the total population of 32 students out of that, $56.3 \%$ of respondents, are strong enough in the internet challenges, and only $6.3 \%$ of the respondents are weak to used internet. The data categories of internet facilities in Gambia vocational schools are presented in Figure 2.

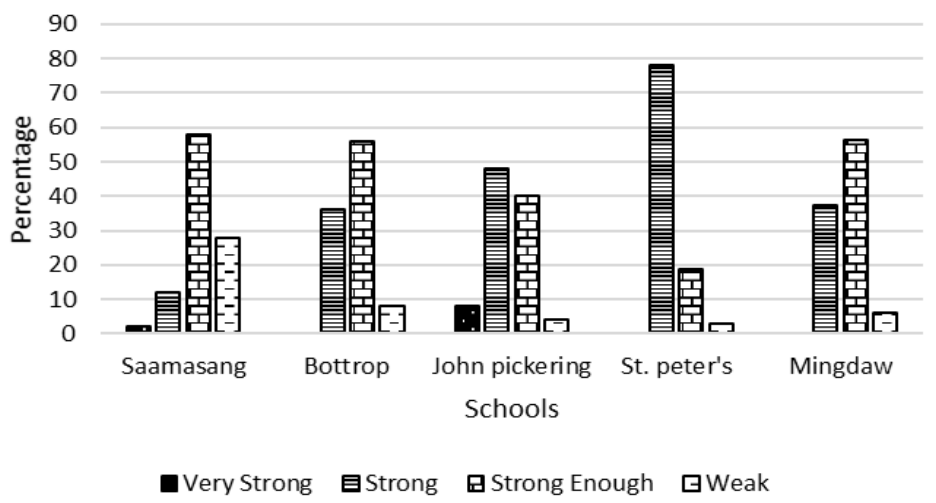

Figure 2. Data Categories of Internet Facilities in Gambia Vocational Schools

\section{Instructional Media Quality}

Internet facilities are a substantial factor in this study to determine the respondents' responses and actions related to the research questionnaire. It affects how people are aware of the process of media learning in the educational sector, especially the role of media in the teaching and learning process in vocational schools [17]. The level of understanding of respondents in media learning is shown in Figure 3.

The finding indicated that out of 50 students, $50.0 \%$ of respondents out 50 students, $50.0 \%$ of respondents from Saamasang are secure enough in instructional media but, 32.0 $\%$ of the respondents are weak in instructional media, Saamasang started using the computer in schools in 2017 that lead to a profound understanding of respondents to used instructional media in class. The total sample of
25 respondents from Bottrop is a private school located in the Brikama west coast region of the county.

From the analysis, out of $64.0 \%$ of the respondents are secure enough in media learning, $4.0 \%$ of respondents are extremely unable to use learning media. While in John Pickering from the total population of 25, 48.0 $\%$ of the respondents are strong enough in instructional media, and $8.0 \%$ of the respondents are robust to cope with instructional media learning. St. Peter's is a private school located at Lamain in the west coast region of the country, St. Peter's has adopted using the computer in 2008. From the population of the study, 32 students answered the questionnaire. Out of that, $50.0 \%$ of respondents are strong in instructional media, and $3.1 \%$ of respondents are weak to used instructional media. While in Mindgaw, the total population of 32 students in grade 10 class 
answers the questionnaire, from observation 59.

$4 \%$ of respondents are secure in instructional medial, but only $3.1 \%$ of the respondents are illiterate to used instructional media.

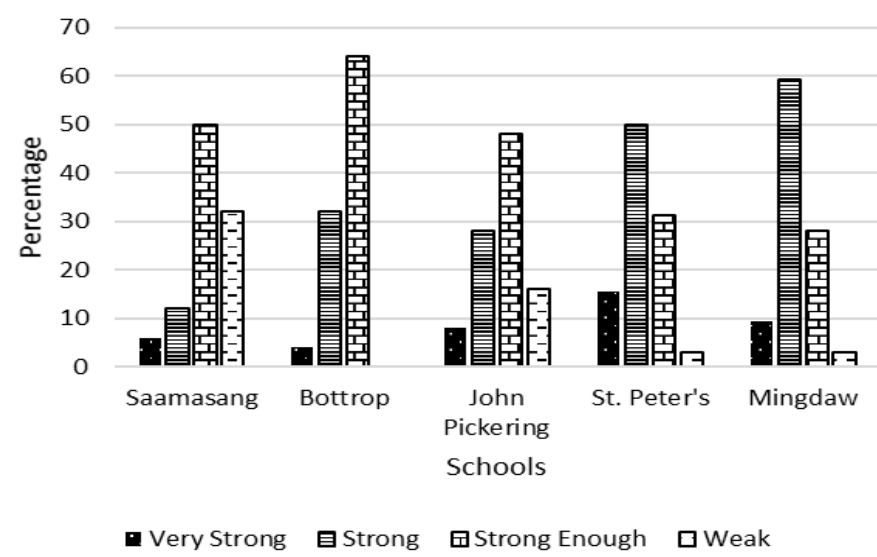

Figure 3. Data Categories of Instructional Media in Gambia's Vocational Schools

\section{The Challenges of ICT}

As described in Figure 4, the finding indicated the overall challenges of (ICT) in five vocational schools. The result shows that 60.0 $\%$ of the respondents are strong enough in the challenges of ICT, while $32.0 \%$ of respondents are weak in ICT's overall challenges in Saamasang. From the analysis in Bottrop, 76\% of the respondents are strong enough in ICT's overall challenges [18]. In contrast, at John Pickering, $72.0 \%$ of the respondents are strong enough in challenges to used ICT, and whereas $4 \%$ of the respondents are weak in the challenges of ICT in John Pickering. From the observation, most of the respondents in St. Peter's $56.3 \%$ respondents are strong in the challenges of ICT, and $3.1 \%$ of respondents are weak in the overall challenges of ICT in St.
Peter's. From the analysis, half of the respondents from Mingdaw 50.0 \% of respondents are strong enough to the challenges of ICT, while only $6.3 \%$ of the respondents are weak in the challenges of ICT.

The result was correlated among five vocational schools in the challenges of computer knowledge, internet facilities, instructional media, and overall challenges. The correlation for computer knowledge revealed that there is no significant difference among the five schools in the challenges of computer knowledge. It means that there is the same challenge of computer knowledge in five schools from the result. The p-value of these variables is all greater than the 5\% level significance. The conclusion is that there are no different challenges in computer knowledge among the five schools.

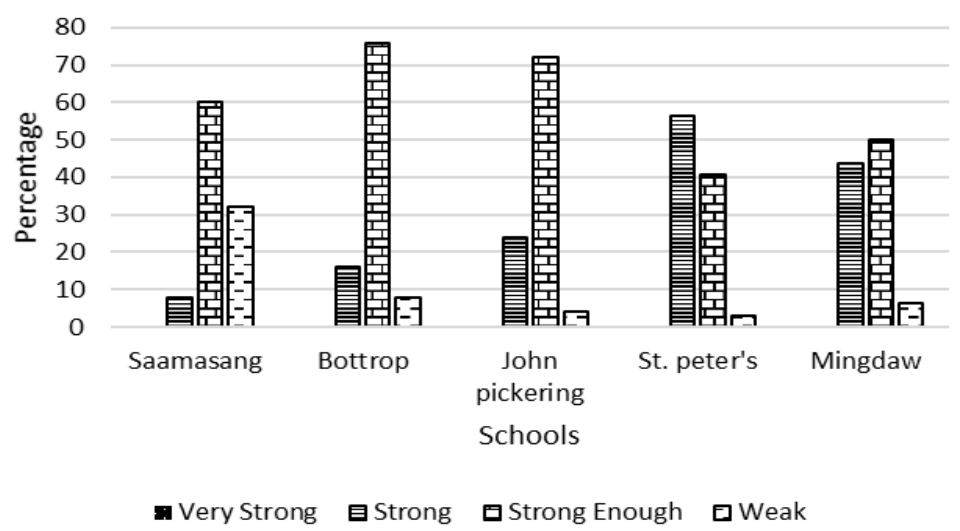

Figure 4. Data Categories of Overall Challenges in Gambia Vocational Schools 
Table 1. Correlation Results Among Five Vocational Schools in the Gambia

\begin{tabular}{|c|c|c|c|c|c|c|c|c|c|c|c|c|c|c|c|c|c|c|c|c|}
\hline \multirow{3}{*}{$\begin{array}{c}\text { Vocational } \\
\text { High } \\
\text { School }\end{array}$} & \multicolumn{20}{|c|}{ Significant } \\
\hline & \multicolumn{5}{|c|}{ Computer Knowledge } & \multicolumn{5}{|c|}{ Internet Facilities } & \multicolumn{5}{|c|}{ Instructional Media } & \multicolumn{5}{|c|}{ Overall Challenges } \\
\hline & 1 & 2 & 3 & 4 & 5 & 1 & 2 & 3 & 4 & 5 & 1 & 2 & 3 & 4 & 5 & 1 & 2 & 3 & 4 & 5 \\
\hline Saamasang & . & .838 & .308 & .387 & .511 & . & .684 & .703 & .296 & .701 & & .333 & .870 & .839 & .735 & . & .971 & .704 & .774 & .469 \\
\hline Bottrop & .838 & . & .809 & .791 & .294 & .684 & . & .718 & .692 & .000 & .333 & . & .669 & .895 & .149 & .971 & . & .965 & .321 & .084 \\
\hline $\begin{array}{c}\text { John } \\
\text { Pickering }\end{array}$ & .308 & .809 & . & .609 & .901 & .703 & .718 & . & .647 & .851 & .870 & .669 & . & .230 & .053 & .704 & .965 & . & .777 & .010 \\
\hline St. Pteter's & .387 & .791 & .609 & . & .692 & .296 & .692 & .647 & . & .862 & .839 & .895 & .230 & . & .435 & .744 & .321 & .777 & . & .943 \\
\hline Mingdaw & .511 & .294 & .901 & .692 & . & .701 & .000 & .851 & .862 & . & .735 & .149 & .053 & .435 & . & .469 & .084 & .010 & .943 & . \\
\hline
\end{tabular}

For internet facilities, there is a significant difference in the challenges of internet facilities. Bottrop and Mingdaw schools have a significant $\mathrm{p}$-value of .000 comparing to other schools. Both of them have a p-value less than 0.05 or a $5 \%$ level. It means that there is a different challenge of internet facilities among five vocational schools.

The correlation result of instructional media compared among five schools. The results found no significant difference among schools in the challenges of instructional media. This means all schools have the same challenges in instructional media. Overall, the result revealed that there is no significant difference among the five schools in overall challenges of instructional media. Mingdaw school and John Pickering school have the same difficulties in ICT with the p-value of 010. This means that there is no significant difference between Mingdaw and John Pickering in instructional media.

This section is also devoted to presenting statistical findings on the factors related to the challenges of ICT in the Gambia. It also further discusses the result of the factors perceived to impede the effectiveness of ICT. The researchers gave some recommendations for ICT.

The practical implementation of ICT courses at Vocational High School cannot be fully achieved without drawbacks, either material or human. Many problems occur in the implementation of ICT for the development of required knowledge, and the researcher identified competency[19]. This study identified some measures of challenges of ICT in five schools in The Gambia. Among these challenges are lack of irregular power supply to the use of computers in the Gambia, poor connection of internet, lack of infrastructure (classroom) to accommodate all the students, lack of trained teacher of ICT to teaching students; and lack of sufficient computer[20]. Students who enroll in one class are up to fifty students. In the Gambia, it has been noted that most ICT in schools lack competent and trained ICT teachers. ICT is not well structured in the educational curriculum system, which leads to severe challenges of ICT in schools at the moment [21].

In the aspects of the application of computer knowledge in Saamasang Vocational Senior High School, the study found that student computer knowledge was weak in keeping and accessing ICT. $68.0 \%$ of students are literate in computer knowledge, $28.0 \%$ of students are strong enough with computer knowledge, while $4.0 \%$ have a strong knowledge of computers. The same challenges applied to students in St. Peter's. 37.5\% of the student are literate in computers. Computer knowledge is feeble at Saamasang and St. Peter's, and it needs to be improved. Spearman's correlation analysis was used to compare the challenges of ICT among five schools, but there were no differences in schools' challenges for computer knowledge. They all have the same problems, as shown in Table 1. The results revealed that Saamasang, John Pickering, and St. Peter's are the same in internet facilities' challenges but different from Bottrop and Mingdaw internet facilities [22].

The finding of this study revealed that internet facilities, computer knowledge, and instructional media need to be improved from 
the statistical analysis result shown in the bar charts. The teacher in Saamasang aware of the current problem concerning ICT systems in the Saamasang. These studies were conducted to apply to the five deference private vocational schools, and it inducted that most of the schools are facing the same challenges. Likewise, in Saamasang always if higher demand for internet connection. Many people face a slow, poor, and weak internet connection. The internet is beneficial now in this generation. Most of the research is online, facilitating the natural movement of teaching and learning in school[18]. However, to achieve a better education system, the Gambia government should improve internet facilities.

\section{CONCLUSION}

Information and communications technology (ICT) helps teachers and learners to be fully corporative in the teaching and learning process. ICT also improves their thinking knowledge and helps them to conduct various educational activities in the educational sector. Various kinds of technologies, like the Internet, computers, laptops, and mobile phones, are used as instructional media and make learning more enjoyable. The four GSM operators in the country should reduce the cost of mobile data to affordable prices so that every Gambian can afford to buy data to be able to have access to the internet. They should increase the coverage of internet facilities across the country to have access to the Internet. The study has recommended future research to be conducted in government schools, universities, and colleges in the Gambia about the challenges of ICT. From the finding of the result of computer knowledge and internet facilities and instructional media are the most difficult challenges currently at vocational schools. This study suggests that teachers have opportunities to improve in applying ICT for enhancing learning quality in the Gambia.

\section{REFERENCES}

[1] Marathe, "Role of ICT in higher education in global era," Int. J. Eng. Sci. Res. Technol., vol. 8, no. 9, pp. 1-5, 2019, doi: 10.5281/zenodo.3392190.

[2] C. Fuchs, "Information technology and sustainability in the information society," Int. J. Commun., vol. 11, no. 688768, pp. 2431-2461, 2017.

[3] H. Rahman, "The role of ICT in open and distance education," Turkish Online J. Distance Educ., vol. 15, no. 4, pp. 162-169, 2014.

[4] H. Abdullahi, "The role of ICT in teaching science education in schools," Int. Lett. Soc. Humanist. Sci., vol. 19, pp. 217-223, 2014.

[5] M. E. Ismail et al., "Factors that influence students' learning: An observation on vocational college students," J. Tech. Educ. Train., vol. 11, no. 1, pp. 93-99, 2019, doi: 10.30880/jtet.2019.11.01.12.

[6] S. Ghavifekr, T. Kunjappan, L. Ramasamy, and A. Anthony, "Teaching and learning with ICT tools: issues and challenges from teachers' perceptions," Malaysian Online J. Educ. Technol., vol. 4, no. 2, pp. 38-57, 2015.

[7] H. Salehi and Z. Salehi, "Challenges for using ICT in education: Teachers' insights," Int. $J . \quad e$-Education, eBusiness, e-Management e-Learning, vol. 2, no. 1, 2012.

[8] H. Singh, "Role of ICT in educational planning in India," Int. J. Eng. Manag. Res., vol. 8, no. 1, pp. 189-193, 2018.

[9] A. Cloete, "Technology and education : Challenges and opportunities," HTS Teol. Stud. Stud., no. October 2017, pp. 1-7, 2017, doi: 10.4102/hts.v73i3.4589.

[10] J. Fouts, "Research on computers and education: Past, present and future," Seattle, WA Bill Melinda Gates Found., pp. 1-55, 2000. 
[11] A. Wafi, A. Rahman, H. Harun, N. Anis, and I. Aqiah, "The usage of mobile application to teach practical skills among catering students," J. Pendidik. Teknol. dan Kejuru., vol. 25, no. 1, pp. 31-35, 2019, doi: 10.21831/jptk.v25i1.22920.

[12] International Trade Centre Republic of the Gambia, "Strategic Youth and Trade Development Roadmap of the Gambia 2018-2022," 2018.

[13] A. A. Sakat, M. Zaid, M. Zin, R. Muhamad, A. Ahmad, and U. Putra, "Educational technology media method in teaching and learning progress," vol. 9, no. 6, pp. 874-878, 2012, doi: 10.3844/ajassp.2012.874.878.

[14] A. Ogaga, G. A. Igori Wallace and Egbodo Benson, "Effects of instructional materials on the teaching and learning of social studies in secondary schools in Oju local government area of Benue state," Int. $J$. Curr. Res., vol. 8, no. 7, pp. 33859 33863, 2016.

[15] H. Azkiya and S. G. Sari, "Problems faced by the teacher in maximizing the use of learning media in Padang," vol. 24, no. 1, pp. 60-66, 2017.

[16] D. N. Burrell, "Improving the quality of ' the internet of things, instruction in technology management, cybersecurity , and computer science," vol. 16, no. 2, pp. 59-70, 2020, doi: 10.4018/IJICTE.2020040105.
[17] D. Pernanda, M. A. Zaus, R. Wulansari, and S. Islami, "Effectiveness of instructional media based on interactive cd learning on basic network at vocational high school: improving student cognitive ability," vol. 2018, pp. 443-447, 2018.

[18] A. A. Malekani, "Access to, use and challenges of ICTs in secondary schools in Tanzania: a study of selected secondary schools in Morogoro Municipality," Inf. Impact J. Inf. Knowl. Manag., vol. 9, no. 2, p. 44, 2018, doi: 10.4314/iijikm.v9i2.4.

[19] R. O. Pratama, "Teachers' challenges of ICT implementation in rural and urban vocational high schools," Universitas Majalengka, 2019.

[20] A. Kettunen and P. James, "Challenges in implementing ICT in career services: perspectives from career development experts," Int. J. Educ. Vocat. Guid., vol. 19, pp. 1-18, 2019, doi: 10.1007/s10775-018-9365-6.

[21] G. W. Kennedy, U. S. Udoetuk, and S. I. Ufot, "Challenges of technical vocational teacher education and teaching in Nigeria: The need for intervention," Int. J. Educ. Eval., vol. 3, no. 7, pp. 71-82, 2017.

[22] A. Dia and B. Jammeh, "A study of the employability of upper basic school leavers in Gambia, Nigeria and Senegal," Eur. J. Educ. Stud., vol. 4, no. 5, pp. 331-350, 2018, doi: 10.5281/zenodo. 1240550 . 